
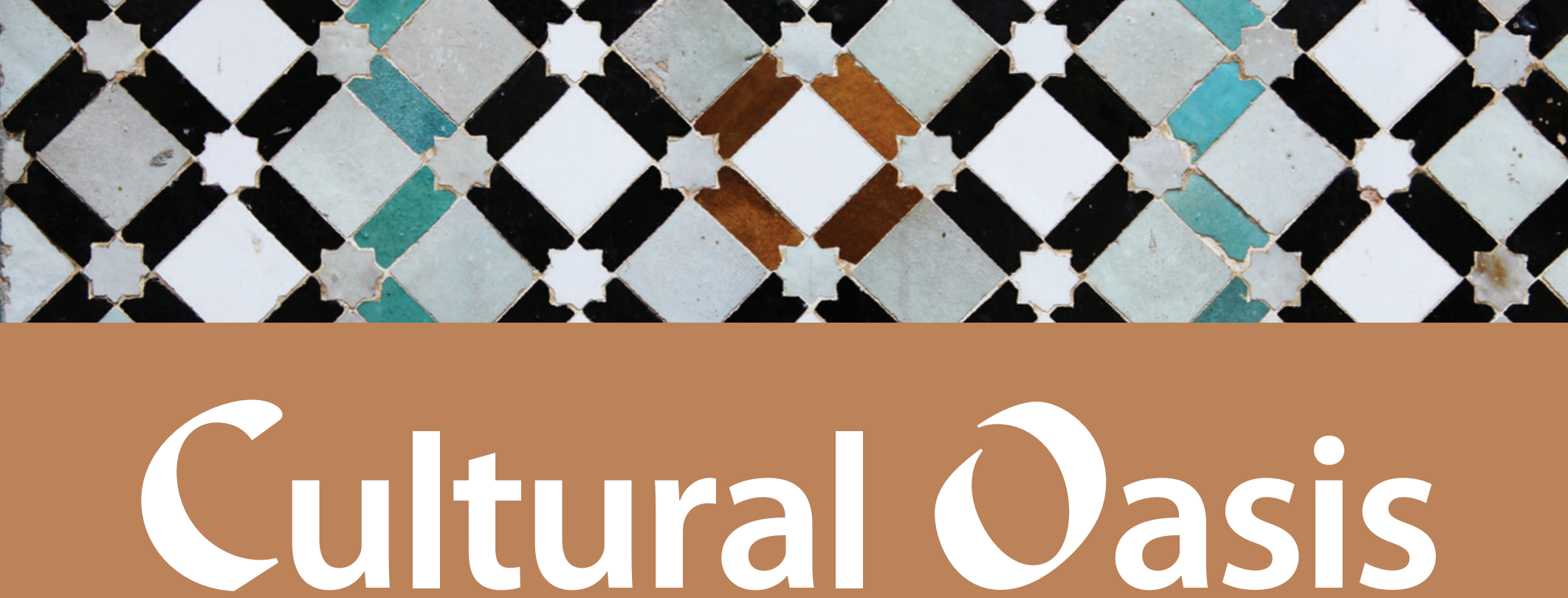

\title{
For Arab Children, Collected Works Offer Roads to Tolerance, Critical Thinking
}

By Gail L. Zellman, Jeffrey Martini, and Michal Perlman

Gail Zellman is a RAND senior research psychologist with years of experience conducting and leading research on child and youth policy. Jeffrey Martini is a RAND Middle East analyst who focuses on political reform in the Arab world.

Former RAND researcher Michal Perlman is an associate professor in the Department of Applied Psychology and Human Development at the University of Toronto.

Violent reactions to provocative films and cartoons about Islam have left many people around the world more appalled by the reactions than by the provocations. In 2004, Dutch director Theodoor van Gogh was assassinated because of his film about the treatment of women in Islam. Since 2005, Danish cartoonist Kurt Westergaard has been the target of several murder attempts because of his depictions of the prophet Mohammed. In 2012, deadly anti-American protests swept the Arab world because of an amateurish anti-Islamic video posted on YouTube. This violent intolerance of opposing views has caused many observers to wonder how tolerance and critical thinking could be nurtured in the Arab world. 


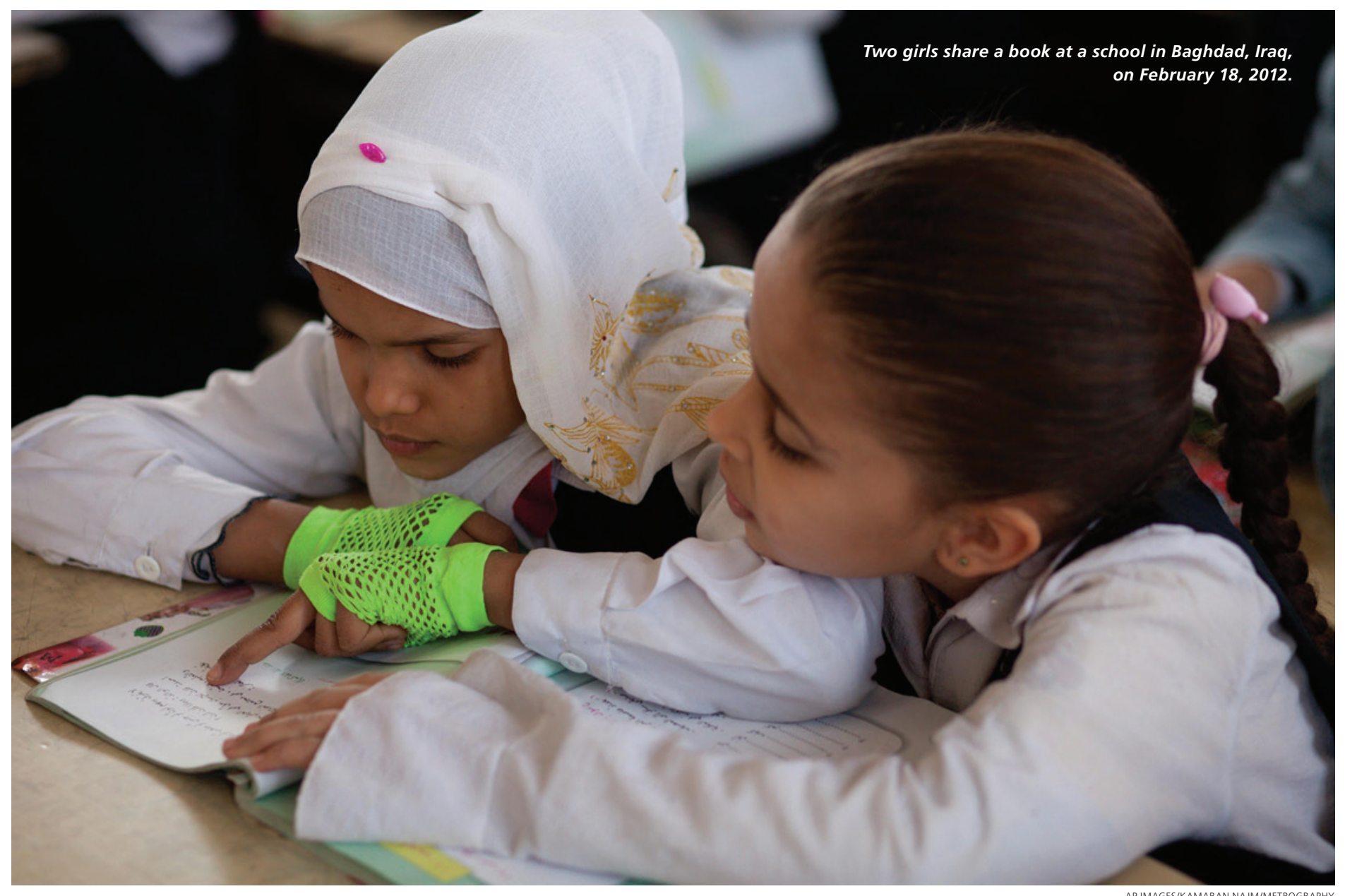

This is not just a Western concern. There is widespread awareness within the Arab world itself that this region, for the sake of its own human development, needs to cultivate a well-educated citizenry open to new ideas and capable of challenging the intolerant ideas of others. One way to cultivate such a citizenry in the Arab world is to capitalize on the rich cultural resources already being produced in Arabic that reinforce tolerance, promote new ideas, and support the development of critical thinking.

Our research on this topic stems from the idea that focusing on Arabic-language materials targeted to children could be especially effective. By the time people reach adulthood, it can be much more difficult for them to entertain new ideas that challenge long-held beliefs. But we were not sure whether good materials were being produced for Arab children, and there was no reliable way to identify the materials. For these reasons, we developed criteria for children's works that promote tolerance and critical thinking. We then conducted a wide search, across a range of media, for Arabic-language children's works that showed promise of meeting the criteria. Of the
104 works that we collected, 68 did meet them. Most of these works are short stories, reflecting the scarcity of original Arabic-language materials available in other media, such as cartoons.

Civil society groups and educators in the Arab world could work with libraries, bookstores, schools, and cultural centers to bring these materials to a wider audience. It would also be useful, given the low literacy levels in much of the Arab world, to adapt these printed works for other media, notably television. Airing such programs during Ramadan would be particularly attractive given the cultural norm of families watching television after breaking the fast.

Identifying and disseminating these materials is important in the Arab world because, with few exceptions, the educational environment does not foster tolerance or critical thinking. Traditional education systems in this part of the world generally rely on rote memorization and preach deference to authority. Qatar is a noteworthy exception because of its $\mathrm{K}-12$ education reform, a key goal of which is to inculcate critical thinking skills. 


\section{In Search of Tolerance}

Tolerance has been defined as a fair, objective, and permissive attitude toward those whose opinions, practices, race, religion, nationality, and other traits differ from one's own; in short, freedom from bigotry. Critical thinking is generally viewed as the ability to decide, independent of reward and punishment, between right and wrong in the moral realm and between truth and falsehood in the intellectual realm. Such abilities should be a central goal of education.

To nurture these abilities, targeting youth has three advantages. First, children's materials can offer constructive messages at a time when ideas about in-groups and out-groups are just forming; there is less need to counter intolerant beliefs. Second, messages of tolerance can be presented in a nonpolitical form that is less likely to upset parents or other authority figures. Third, the combination of the "youth bulge" in the Arab world and the fact that young people are far more likely than their parents to be literate translates into a much larger potential audience for children's materials than for adult materials.

There are particularly large differences in literacy rates between adults in general (people over the age of 15) and young adults (those of ages 15-24) in the following Arab countries: Algeria (70 percent versus 90 percent), Egypt (71 percent versus 85 percent), Morocco (52 percent versus 71 percent), Sudan (61 percent versus 77 percent), and Tunisia (74 percent versus 94 percent). All data are from the 2009 Arab Human Development Report.

In identifying the desired content of children's materials, we were influenced primarily by social learning theory, which highlights the extent to which people learn through observation and imitation. We screened for materials in which diverse characters either got along with each other or paid a price for not getting along. We also scored materials based on the accessibility of their messages to children of different ages and the degree to which their presentational elements made materials engaging and persuasive. Three Arabic-speaking project staff members identified and reviewed the materials that held promise for meeting our goals. The reviewers applied the screening criteria and coded the works in a formal, consistent way, resulting in the 68 materials in our final repository.

\section{The Collection Takes Shape}

We found a large body of children's literature indigenous to the Arab region that promotes tolerance and critical thinking. A number of works even take on taboo or otherwise sensitive subjects, such as the tale of a young boy whose divorced parents share custody and cooperate in parenting him, or that of a teenage boy who is abused by his alcoholic father.

The rejected works generally paid insufficient attention to constructive themes. Particularly in materials for the youngest group (ages 4-6), the value of obedience often overshadowed messages about tolerance or support for critical thinking. We disqualified materials that promoted intergroup understanding at the expense of another group. One rejected book, for example, encouraged unity between Christian and Muslim Palestinians in order to unite against Israeli occupation. Another rejection criterion concerned the outcome of the critical thinking process portrayed. If the end result was greater support for intolerance or greater adherence to a traditional belief system, we did not accept the material. We rejected, for example, one story because its protagonist opposed rules that limited fasting during Ramadan to older children only. We judged this story to be antithetical to our goals because it promoted greater religious piety than the societal norm.

It should be noted that most of the rejected materials were not promoting intolerance or encouraging blind obedience to norms or rules. The materials simply did not explicitly promote tolerance or critical thinking (or ways to draw different conclusions than those supported by prevailing societal rules, authorities, or assumptions).

We sought balance in the collection at three different levels. We made sure it represented all subregions of the Arab world: North Africa, the Arab Gulf countries, and the Levant (eastern Mediterranean). We sought balance between materials that promoted tolerance and those that promoted critical thinking. And we sought equal representation of materials targeting each of three age groups (4-6 years, 7-10 years, and 11-14 years).

Despite our efforts, the catalog is still weighted toward materials from Levantine authors (those from Jordan, Lebanon, Palestine, or Syria), and more works focus on tolerance than on critical thinking. The least well-represented age group is 4-6-year-olds. We also excluded most cartoons shown in the Arab world, because they are generally dubbed versions of content created in the West and thus do not meet the criterion of being indigenously produced.

\section{Many Signs of Promise}

The process of collecting and then coding Arabic-language children's media revealed a number of positive findings. Perhaps the most significant is that there exists a trove of children's literature indigenous to the region that promotes tolerance, coexistence, and respect for the "other." A second positive finding is the strong sense of mission among many of the creators of these works. To increase their audiences, the authors engage in a range of activities that go well beyond producing content. For example, some of the authors self-publish their works and make a number of their materials freely available online to increase their accessibility, and some conduct teacher training on how best to use the materials and team up with international organizations to spread their messages.

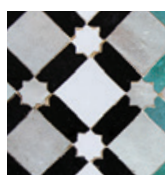

There exists a trove of children's literature indigenous to the region that promotes tolerance, coexistence, and respect for the "other." 
Another promising development is the emergence of Arabiclanguage novels aimed at "tweens," children who are generally between the ages of 10 and 13. This age group has long had to cope with a paucity of materials that are sophisticated enough to be appealing but also accessible in light of often limited reading comprehension skills. In 2006, author Tāriq 'Abd al-Bārī published The King of Things, the first full-length Egyptian novel for this age group. The novel is about a 12-year-old Egyptian boy who becomes the defender of objects (desks, chairs, and buildings) defaced by other students and who then overcomes the bullying directed at him through tolerance, forgiveness, and productive dialogue. Bearing similarities to the Harry Potter series, the novel became a phenomenon in Egypt—necessitating a second print run less than a year after it was released. This suggests a pent-up demand for compelling material written specifically for this age group.

Two exemplary books that take on taboo or sensitive subjects are $I$ Live . . by Hanādī Dīyyah and $A$ Street Kid by Fayrūz al-Ba'lbakki. I Live ... is narrated by a boy who lives with both of his divorced parents. While divorce is not uncommon in the region, the arrangement portrayed in the book-shared custody and continued contact and cooperation between the parents for the sake of the child-describes a family situation that differs substantially from the social norm. A Street Kid describes the experience of a teenage boy who suffers from domestic abuse at the hands of his alcoholic father. Not only does the background of the story shed light on a little-discussed social problem, but the message of the book-that youth should not passively obey authority and should know their legal rights—challenges the prevailing norm of compliant behavior.

Not coincidentally, both authors are Lebanese, and the books were printed and distributed by Levantine publishing houses. The preponderance of literature from the Levant can be traced to the importance of Lebanon to Arab publishing, the religious diversity of the subregion, and a freer environment for the public discussion of sensitive topics.

Another important development was the creation in 2007 of the first three-dimensional movie cartoon from the region. Frij ("Neighborhood" in the Gulf dialect) is set in Dubai and focuses on four female characters who try to reconcile traditional values with the social changes brought about by modernization. While we ultimately rejected this cartoon because its characters reconcile the conflict in favor of conservative values, other three-dimensional cartoons created since, such as the Egyptian show Karäkīb (about a fictional planet), do encourage tolerance and critical thinking. The high production value of these cartoons and the heavy penetration of satellite television programming in the region make these shows a promising vehicle for reaching Arab children.

\section{Persistent Barriers}

While our search revealed a number of heartening trends, it also exposed some daunting weaknesses. The most obvious is the oftenpoor production quality of books published in the region. In one book, pages 37-48 were mistakenly printed in place of pages 73-84, creating a 12-page gap in the novel. Many books suffered from poor-

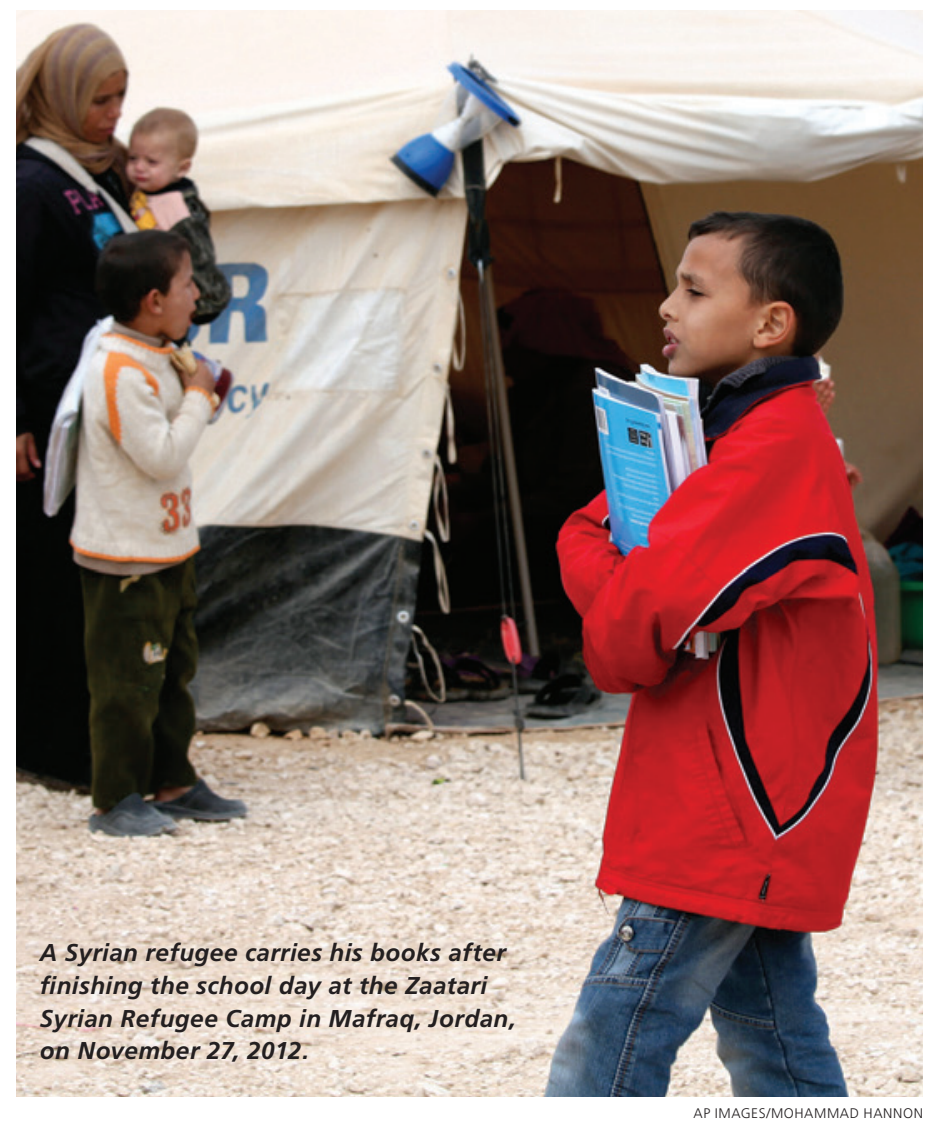

quality paper and printing that made them difficult to read. Other books lacked illustrations; what illustrations did exist were unattractive and not likely to engage young readers. Online content was beset by its own problems: broken links, authors posting text without illustrations, and text abruptly cutting off before the end of the story.

Alongside weaknesses in production quality were deficiencies in content. Some stories contained overly formulaic plots or tired metaphors. The use of a rainbow to represent diversity was so commonplace that we stopped accepting these types of works to avoid redundancy. In other cases, the writing was not engaging; or, in the case of folk tales, it used a stilted form of classical Arabic unlikely to appeal to today's generation of children.

There remains an acute shortage of indigenously produced children's television programming with dynamic and modern production values. The Jordanian production Ben and Izzy and the Egyptian cartoon Karäkìb are notable exceptions. But the high production costs associated with this type of media limit the opportunities for local writers, artists, and producers. Such programs and their messages could have powerful effects in this region, with its low literacy, little tradition of leisure reading, and low levels of Internet connectivity. However, efforts to encourage more of such programming may be fruitless because of severe, prevailing problems with copyrighting. Those who might invest in such programming understand that there are few profits to be made because pirating of material is so widespread in the region; virtually everyone buys pirated DVDs. 


\section{Considerable payoff could come from exploring the roles that parents might play.}

A 2009 RAND study of Arabic-language adult materials with goals similar to ours found that there are few bookstores or public libraries in the region. Equally worrisome, more "liberal" books are often banned, while intolerant literature may be subsidized. RAND work on education reform in the Gulf region found that children's books face yet another hurdle: Rigid, centrally controlled education curricula, whose content might not change for decades, may simply not accommodate pioneering new works. Parents in the Arab world, meanwhile, tend to view the schools and educators as the experts in imparting key cultural values; the parents neither seek nor readily accept this role for themselves.

\section{Policy Prospects}

It would be worthwhile to assess the willingness of key cultural institutions, particularly schools and parents, to help distribute works that support tolerance and critical thinking. A first effort could examine the openness of schools and education ministries to including such materials in their curricula. For instance, the nation of Qatar and the emirate of Abu Dhabi have reformed their education ministries and revised their often rigid, highly prescriptive curricula. New materials might find a place if they were better known, if they were more accessible, and if teachers received training on how to integrate them into lessons and other activities.

Considerable payoff could come from exploring the roles that parents might play. Little is known about how parents throughout the Arab world perceive their roles. According to the United Nations Development Programme's 2003 Arab Human Development Report, "The most common style of child rearing within the Arab family is the authoritarian accompanied by the overprotective." Together, the report asserts, these practices reduce children's independence and initiative, suppress children's inquisitiveness, and discourage freedom of thought.

We need to know more about how parents in the Arab world view their own roles and responsibilities. A survey of parents from different parts of the region could help to clarify the roles that parents see for themselves in promoting open-mindedness, tolerance, and critical thinking. Using some items from a parent survey recently fielded in the West, we are now developing such a survey for Arab parents.

It would also be worthwhile to make the materials we selected widely accessible. Beyond working with libraries, bookstores, schools, and cultural centers, another approach would be to make our catalog available on the web, perhaps by publicizing it on a website such as Curriki, where teachers search for materials. Or by collaborating with libraries, such as the renowned Bibliotheca Alexandrina in Egypt, which makes many of its materials freely available on the web. Or by building on local initiatives, such as al-Hakawati (The Traditional Arab Storyteller) run by The Arab Cultural Trust, which already posts a number of tolerancepromoting children's stories on its website. It would be especially worthwhile, as mentioned above, to convert or adapt the printed works for television.

Including such materials in public and school library collections could also promote tolerance and critical thinking in Arabicspeaking communities in the United States. There are substantial populations of Arabic speakers in the greater Detroit area, Northern Virginia, and other parts of the country. Placing these materials in public collections would reinforce the values of openness and tolerance on which America is based.

Testing the appropriateness of the materials and their shortterm impact on children's attitudes would also be beneficial. Tests of levels of children's tolerance or critical thinking before and after their exposure to some of the materials would provide valuable information about the materials' effectiveness and the utility of the methods used to identify them.

All these efforts could be employed by local policymakers and educators to promote tolerance and critical thinking among Arab children. Such efforts could help to cultivate a knowledge society characterized by openness to other cultures and to new ideas, thereby contributing profoundly to human development across the Arab world.

\section{Related Reading}

Barriers to the Broad Dissemination of Creative Works in the Arab World, Lowell H. Schwartz, Todd C. Helmus, Dalia Dassa Kaye, Nadia Oweidat, 2009, 58 pp., www.rand.org/t/MG879

Education for a New Era: Design and Implementation of $K-12$ Education Reform in Qatar, Dominic J. Brewer, Catherine H. Augustine, Gail L. Zellman, Gery W. Ryan, Charles A. Goldman, Cathleen Stasz, Louay Constant, 2007, 216 pp., www.rand.org/t/MG548

Identifying Arabic-Language Materials for Children That Promote Tolerance and Critical Thinking, Gail L. Zellman, Jeffrey Martini, Michal Perlman, 2011, 84 pp., www.rand.org/t/TR856

Implementation of the K-12 Education Reform in Qatar's Schools, Gail L. Zellman, Gery W. Ryan, Rita Karam, Louay Constant, Hanine Salem, Gabriella C. Gonzalez, Charles A. Goldman, Hessa Al-Thani, Kholode Al-Obaidli, 2009, 196 pp., www.rand.org/t/MG880

\section{"Cultural Oasis" first appeared in the Winter 2012 - 2013 issue of RAND Review.}

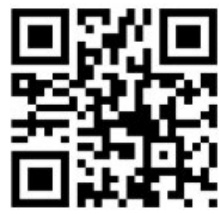

View the congressional briefing on the Arabic Children's Literature Project 


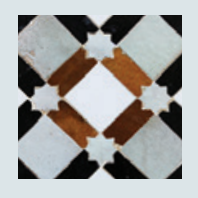

\section{Recommended Stories}

\section{for Schools, Libraries, and Wider Distribution}

Below is a sampling of Arabic-language titles that promote diversity, positive relationships, tolerant behavior, and/or critical thinking.

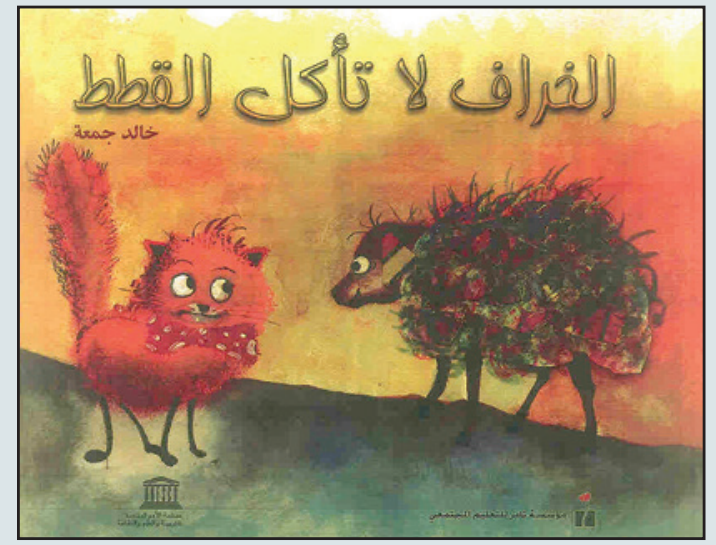

For Children Ages 4-6

Sheep Don't Eat Cats, by Khālid Jum'ah, published by Tamer Institute for Community Education (Ramallah, Palestinian territories), 2005

This is the story of a family of cats frightened by their new neighbors, a family of sheep. Father cat forbids intermingling with the sheep. However, the curiosity of the youngest cat leads to an exchange with the sheep that confirms they mean no harm to the cats.
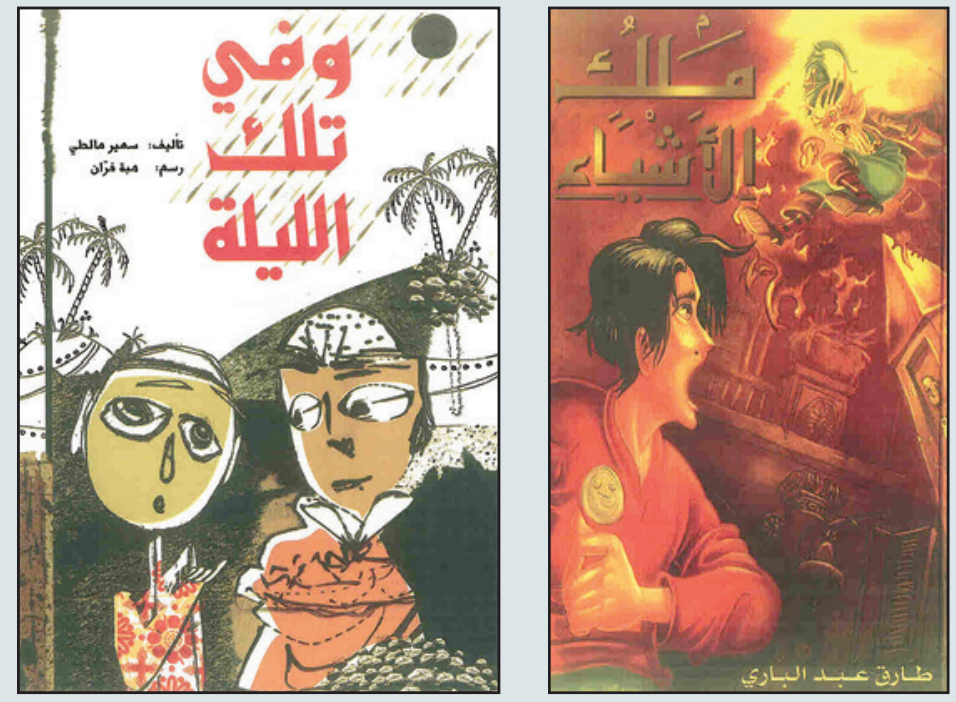

For Children Ages 11-14

And on That Night, by Samīr Māltī, published by Asala Publishing House (Amman, Jordan), 2009

Two sons of warring tribes take it upon themselves to uncover the water source that has divided the people of their oasis. When the two boys, who are best friends, do this, the water gushes forth, awakening the tribe members and spurring the sheikhs to reconcile.

The King of Things, by Tāriq 'Abd al-Bārī, self-published, 2006 A 12-year-old Egyptian boy becomes the defender of objects defaced by other students and overcomes the bullying directed at him through tolerance, forgiveness, and productive dialogue.

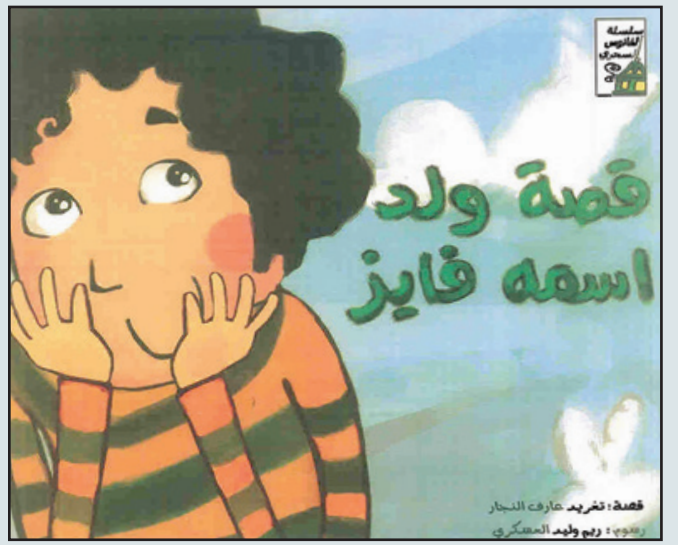

For Children Ages 7-10

The Story of a Boy Named Fayez, by Taghrīd 'Ārif al-Najjār, published by Al-Salwa Publishing House

(Amman, Jordan), 2008

Fayez receives poor grades in art class because he takes artistic license, displeasing the instructor. While learning stone masonry, Fayez carves stones into impressive shapes and ends up being recruited by an art institute, where he becomes a popular star pupil.

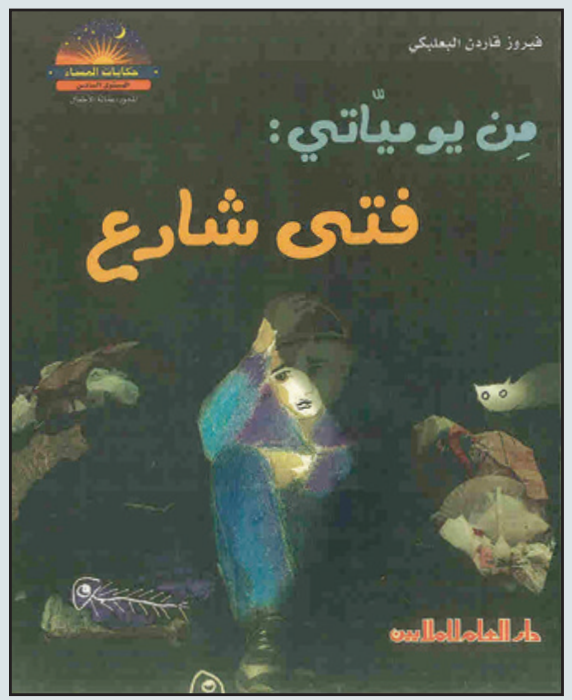

\section{For Children Facing Difficult Situations}

I Live ... , by Hanādī Dīyyah, published by Asala Publishing (Beirut, Lebanon), 2008 (cover image unavailable)

This is the story of a boy who lives with both of his divorced parents. The arrangement portrayed describes a family situation that differs substantially from the social norm.

A Street Kid, by Fayrūz al-Ba'lbakkī, published by Dar al-Fikr (Damascus, Syria), 2007

A teenage boy suffers from domestic abuse at the hands of his alcoholic father. This story sheds light on a taboo social problem while challenging the norm of compliant behavior. 


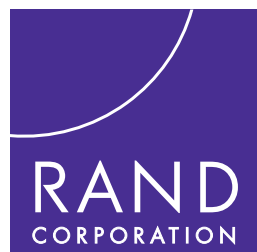

CHILDREN AND FAMILIES

EDUCATION AND THE ARTS

ENERGY AND ENVIRONMENT

HEALTH AND HEALTH CARE

INFRASTRUCTURE AND

TRANSPORTATION

INTERNATIONAL AFFAIRS

LAW AND BUSINESS

NATIONAL SECURITY

POPULATION AND AGING

PUBLIC SAFETY

SCIENCE AND TECHNOLOGY

TERRORISM AND HOMELAND SECURITY
The RAND Corporation is a nonprofit institution that helps improve policy and decisionmaking through research and analysis.

This electronic document was made available from www.rand.org as a public service of the RAND Corporation.

\section{Support RAND}

Browse Reports \& Bookstore

Make a charitable contribution

\section{For More Information}

Visit RAND at www.rand.org

Explore the RAND Corporation

View document details

\section{Corporate Publications}

This product is part of the RAND Corporation corporate publication series. Corporate publications describe or promote RAND divisions and programs, summarize research results, or announce upcoming events.

\section{Limited Electronic Distribution Rights}

This document and trademark $(s)$ contained herein are protected by law as indicated in a notice appearing later in this work. This electronic representation of RAND intellectual property is provided for noncommercial use only. Unauthorized posting of RAND electronic documents to a non-RAND website is prohibited. RAND electronic documents are protected under copyright law. Permission is required from RAND to reproduce, or reuse in another form, any of our research documents for commercial use. For information on reprint and linking permissions, please see RAND Permissions. 